\title{
POTENSI DAN PEMANFAATAN MAT A AIR SIKUMBANG DESA PULAU SARAK PADA KAWASAN HUTAN LARANGAN ADAT RUMBIO KAMPAR-RIAU
}

\author{
Taufik Hidayat ${ }^{1)}$, Emy Sadjati ${ }^{2)}$, Enny Insusanty ${ }^{2)}$ \\ 1) Mahasiswa Fakultas Kehutanan Universitas Lancang Kuning \\ 2) Staf Pengajar Fakultas Kehutanan Universitas Lancang Kuning \\ JIn. Yos Sudarso Km. 8 Rumbai Pekanbaru Riau \\ Email :topikhdt64@yahoo.co.id, emy_mnhunilak@gmail.com, annovisa@yahoo.com
}

\begin{abstract}
ABSTRAK
Hutan Larangan Adat Rumbio memiliki sumber mata air bersih yang dikenal dengan sebutan mata air Sikumbang yang dimanfaatkan masyarakat Desa Pulau Sarak dalam bentuk usaha penjualan air. Tujuan penelitian ini adalah untuk mengetahui potensi dan manfaat mata air Sikumbang yang ada di Desa Pulau Sarak pada Kawasan Hutan Larangan Adat Rumbio, serta untuk mengetahui kelembagaan dan pengelolaan mata air Sikumbang yang ada di Desa Pulau Sarak. Metode penelitian menggunakan metode survei dengan melakukan wawancara dan kuisioner. Hasil penelitian menunjukkan terdapat 8 (delapan) pengelola mata air Sikumbang yang berjumlah 41 kran dengan total debit air sebesar 8,992 liter/detik. Dari semua pengelola itu bisa menjual 103.500 jerigen air perbulan, dan tiap jerigennya bervolume 30 liter air. Kelembagaan dalam pemanfaatan mata air Sikumbang di Desa Pulau Sarak belum ada dilakukan secara formal. Sampai saat ini untuk pemanfaatan dan pengelolaan mata air Sikumbang masih dilakukan secara individu. Dalam pengelolaan mata air Sikumbang, belum ada diterapkannya peraturan oleh pemerintah Desa Pulau Sarak maupun dari tokoh adat. Hasil kesepakatan antara pengelola dengan pemerintah Desa Pulau Sarak, setiap pengelola diwajibkan memberikan sumbangan Rp.125.000,- tiap bulannya. Pembeli air diharuskan memberi sumbangan sebesar Rp.4000,- sekali jalan untuk kenderaan angkutan mobil dan Rp.2000,- untuk kendaraan berjenis becak. Hasil sumbangan yang diberikan kepada Desa Pulau Sarak akan digunakan untuk pembangunan insfrastruktur desa.
\end{abstract}

Kata kunci : Mata air, potensi, Hutan Adat, Rumbio. 